\author{
dr hab. prof. nadzw. Eugeniusz KOŚMICKI \\ Wydział Ekonomiczno-Społeczny, Uniwersytet Przyrodniczy w Poznaniu \\ e-mail: e.h.kosm@gmail.com
}

\author{
dr hab. Dariusz PIEŃKOWSKI \\ Wydział Ekonomiczno-Społeczny, Uniwersytet Przyrodniczy w Poznaniu \\ e-mail: darpie_xl@wp.pl
}

DOI: $10.15290 /$ ose.2016.03.81.03

\title{
W POSZUKIWANIU NOWEJ KONCEPCJI OCHRONY PRZYRODY - IDEA RENATURALIZACJI
}

\begin{abstract}
Streszczenie
Ochrona przyrody ma ważne znaczenie we wszystkich dyskusjach o stanie przyrody i występujących obecnie problemach i konfliktach ekologicznych. Współcześnie jej elementem jest szeroko rozumiana koncepcja renaturalizacji odnosząca się nie tylko do odtwarzania stanów natury, ale również do ochrony procesów przyrodniczych. Ekologia renaturalizacji ma charakter transdyscyplinarny i uwzględnia zarówno specyfikę systemów przyrodniczych, jak i uwarunkowania społeczno-gospodarcze ich rozwoju. Renaturalizacja powinna być także komponentem procesu zrównoważonego gospodarowania i dyskusji nad możliwościami substytucji kapitału naturalnego kapitałem antropogenicznym czy problematyką wyceny świadczeń ekosystemów.

Słowa kluczowe: ochrona przyrody, ekologia renaturalizacji, rozwój zrównoważony, sozologia

\section{IN SEARCH OF A NEW CONCEPT OF NATURE PROTECTION - THE IDEA OF RESTORATION}

Summary

Nature protection is important in all discussions about the state of nature and the currently existing ecological problems and conflicts. The widely nowadays-understood concept of restoration is an element of it; and it is related not only to the states of nature, but also to the protection of natural processes. Restoration ecology is a trans-disciplinary and includes not only the specificity of natural systems, but also the socioeconomic determinants of their development. Restoration should also be a part of the process of sustainable economics; and discussions on the substitution possibilities of natural capital asset by anthropogenic ones as well as the issue ofevaluation of ecosystem services.
\end{abstract}

Key words: nature protection, restoration ecology, sustainable development, sozology

JEL: Q57 


\section{Wstęp}

Pojęcie ochrony przyrody ma ważne znaczenie we wszystkich dyskusjach o stanie przyrody i występujących obecnie problemach i konfliktach ekologicznych. Przyroda znajduje się bowiem pod wszechstronnym, niekiedy zamierzonym, oddziaływaniem człowieka, a jej dalsze trwanie ostatecznie zależy od oddziaływań ludzkich, w tym działań określanych jako ochrona przyrody. Obejmuje ona ochronę: gatunków, biotopów, krajobrazów, a więc utrzymanie, rozwój, ponowne osiedlanie lub odtwarzanie często, chociaż nie zawsze, zagrożonych lokalnie albo globalnie organizmów żywych czy wspólnot życia, ich abiotycznych podstaw, jak również utrzymanie określonych struktur i typów krajobrazów. Jest przy tym charakterystyczne, że pojęcie krajobrazu zawiera aspekty historii społeczno-kulturowej, a także określone walory estetyczne.

Problem renaturalizacji stanowi ważne wyzwanie dla współczesnej ochrony przyrody i procesu gospodarowania. Potoczne rozumienie renaturalizacji, jako ponowne odtworzenie obszarów życia zbliżonych do naturalnych, aktualnie wydaje się nadmiernie uproszczone. Renaturalizacja we współczesnym, szerszym znaczeniu ma na celu kształtowanie środowiska życia człowieka, aby elementy przyrody łączyły się w sposób zrównoważony z wytworami: gospodarki, techniki i rozwoju społeczno-kulturowego.

Zagadnienie renaturalizacji w tym powyższym, szerokim rozumieniu nawiąuje do rozważań nad problematyką trwałości kapitału naturalnego podejmowanych w działaniach gospodarczych oraz świadczeń ekosystemów. Z perspektywy rozwoju zrównoważonego podstawowe problemy związane aktualnie $z$ procesem gospodarowania w przyrodzie można powiązać z dwiema kwestiami:

- $\quad$ sprawiedliwym dostępem do zasobów naturalnych zarówno obecnych, jak i przyszłych pokoleń;

- utrzymaniem kapitału naturalnego ze względu na jego znaczenia dla procesów gospodarowania.

Najczęściej kwestie sprawiedliwości odnosi się do dyskursów na temat rożnych mechanizmów dystrybucji zasobów w ramach poszczególnych społeczeństw oraz w wymiarze globalnym. Z kolei, problem utrzymania kapitału naturalnego w głównej mierze rozpatruje się z uwagi na rozmaite dyskusje związane z zakresem substytucji kapitału naturalnego kapitałem antropogenicznym. Wobec tego poddano analizie koncepcję renaturalizacji opartą na ochronie procesów przyrodniczych. Celem niniejszego opracowania jest próba naszkicowania koncepcji renaturalizacji we współczesnym rozumieniu tej problematyki jako podstawy nowej koncepcji ochrony przyrody. Renaturalizacja powinna być przesłanką procesu zrównoważonego gospodarowania i rozważań nad możliwościami substytucji kapitału naturalnego kapitałem antropogenicznym czy też problematyką wyceny świadczeń ekosystemów.

\section{Epoka „antropocenu”}

Paul Josef Crutzen określił współczesną epokę w historii Ziemi jako „antropocen” [Crutzen, 2002]. Cechą specyficzną obecnego okresu są znaczne różnice między obec- 
nymi obciążeniami środowiska a tymi, które pochodziły z okresu przedprzemysłowego, tj.:

- uniwersalne (globalne) zamiast problemów punktowych (lokalnych);

- $\quad$ kompleksowe zamiast prostych oddziaływań;

- konieczność zastosowania technologicznie zaawansowanych i naukowych metod oceny współczesnych zagrożeń przyrody (np. promieniowania radioaktywnego);

- nieodwracalne uszkodzenia zamiast krótkookresowych problemów środowiska.

Oddziaływanie antropogeniczne przybiera współcześnie takie formy i zakresy, że coraz bardziej zagrożony staje się sam proces ewolucji przyrodniczej, a także powiązany z nim proces historycznego rozwoju społeczno-ekonomicznego ludzkości. W warunkach globalizacji gospodarki następuje ogromne zagrożenie przyrody i utrata bioróżnorodności. Przy tym zmiana ta ma charakter nieodwracalny, zagrażając podstawom biosfery.

Można się tutaj zgodzić z opinia, że rosnace potrzęyy ciagle powieleszajacej sie ludzkości zjednej strony, a z drugiej dtugookresowa konieczność funkcjonowania gospodarki i prayrody stanowia podstawowe wspótcresne wyzwania. Dla dalszego trwania ludzkiej cywilizacji potrzeba ekologicznych warunków ramowych, które možna jednak żmieniać w niewielkim stopniu [Succow, Jeschke, 2014, s. 21]. W tym kontekście problem renaturalizacji ma kluczowe znaczenie.

\section{Współczesna koncepcja ekologii renaturalizacji}

Już ponad pięć tysięcy lat temu ludzie wykorzystywali powierzchnię rolniczą, która regularnie podlegała odłogowaniu. Taka sensowna zmiana: faza wykorzystania i faza odłogowania była chyba najwcześniejszą wersją renaturalizacji. Innym przykładem jest trwające całe stulecia nadmierne wykorzystanie lasów w Europie, co doprowadziło do powstania wielkopowierzchniowych wrzosowisk. Oznaczało to, że rosnące zapotrzebowanie na drewno nie było pokrywane przez ponowne zalesianie. Na poczatku XVIII wieku spowodowało to powstanie koncepcji rozwoju trwałego i zrównoważonego w gospodarce leśnej (Hans Carl von Carlowitz), która później przyczyniła się do ponownego zalesienia. Zalesienia te należą do najbardziej znaczących historycznie projektów renaturalizacji, które były realizowane w Europie Środkowej.

Potocznie przez 'renaturalizację' rozumie się wtórne odtworzenie „bliskości przyrody”. W praktyce ochrony przyrody, obok ponownego odtworzenia możliwie naturalnych stanów ekosystemów, takich jak: wody płynące, restauracja jezior albo rewitalizacja torfowisk, w coraz większym stopniu renaturalizacja odnosi się także do antropogenicznych obszarów [Renaturierung von Ökosystemen in Mitteleuropa, 2009]. Ważną rolę odgrywa tutaj renaturalizacja górskich obszarów budowlanych, przemysłowych odłogów i byłych miejsc ćwiczeń oddziałów wojskowych. Stopniowo wzrasta znaczenie aktywnego, dalszego rozwoju określonych procesów przyrody. Za sprawą ekologii renaturalizacji jako naukowej dyscypliny upowszechniły się rozważania w tym zakresie.

Analizując renaturalizację, która potocznie oznacza „powrót do przyrody”, trzeba w zasadzie odpowiedzieć na dwa podstawowe pytania: do jakiego stanu przyrody nale- 
ży dążyć i jakie są tego przyczyny? O ich różnorodnych wyobrażeniach świadczą zresztą zróżnicowane i pokrewne pojęcia, a mianowicie: rekultywacja, rewitalizacja, regeneracja, restauracja, rehabilitacja. Podejście ekologii renaturalizacji jest także odmienne od podejścia reprezentowanego przez takie pojęcia, jak ecological engineering albo ecotechnology, gdzie głównie podkreśla się aktywność techniczną.

Powstanie $\mathrm{i}$ instytucjonalizacja ekologii renaturalizacji przejawia się w publikacji podręczników i powstawaniu stowarzyszeń naukowych. Już w roku 1988 założono w USA Society for Ecological Restoration, a w 2001 Society for Ecological Restoration Europe. Pierwsza międzynarodowa konferencja pod nazwą Restoration Ecology odbyła się w 1997 roku w Niemczech. Założono tam także Grupę Roboczą Ekologii Renaturalizacji przy Towarzystwie na rzecz Ekologii. Obecnie już na wielu uczelniach ekologia renaturalizacji stała się stałym składnikiem nauczania i badań. Jednak ekologia renaturalizacji nie jest po prostu stosowaną ekologia, ponieważ w swoich założeniach musi uwzględniać aspekty normatywne. W porównaniu z innymi dyscyplinami naukowymi, ekologię renaturalizacji wyznacza transdyscyplinarne podejście, które charakteryzuje się włączeniem różnorodnych aktorów społecznych (np.: właścicieli ziemi, administracji, opinii publicznej, przemysłu). Stąd też renaturalizacja nie ma jedynie wymiaru przyrodniczego, ale również wymiar: społeczno-ekonomiczny, prawny, etyczny i estetyczny. Jednocześnie procedury renaturalizacji nawiązują do: wzorca rozwoju zrównoważonego, pojemności ekologicznej, ochrony zasobów, zachowania procesów świadczeń ekosystemów czy „śladu ekologicznego” (ecological footprint) [Piechocki i in. 2014, s. 105]. Już w 1965 roku Walery Goetel wprowadził pojęcie sozologii jako nauki. Rozumiano przez nią naukę zajmującą się podstawami ochrony przyrody i jej zasobów, a zarazem zapewnieniem trwałości ich użytkowania na mniejszych lub większych obszarach biosfery zmienianych w wyniku działań antropogenicznych [Encyklopedia Powszechna $P W N, 1976$, s. 240]. Współcześnie pojęcie to można - w znacznej mierze - powiązać z koncepcją ekologii renaturalizacji.

Charakterystyczna jest tutaj definicja renaturalizacji ekosystemów przyjęta przez Stefana Zerbe i Gerhardta Wiegleba [Renaturierung von Ökosystemen in Mitteleuropa, 2009, s. 5]. Według nich, renaturalizacja ekosystemów opiera się na rozwoju, względnie ponownym odtworzeniu przez ludzi mniej lub bardziej zdegradowanych bądź nawet całkowicie zniszczonych ekosystemów w kierunku ich bardziej naturalnego stanu. Ponadto, wymienieni autorzy wskazali trzy cele renaturalizacji, tj.:

1. Ponowne odtworzenie pierwotnego, naturalnego albo możliwie do nich zbliżonego stanu;

2. Ponowne odtworzenie stworzonych przez człowieka obszarów, które pozwolą na zrównoważone funkcjonowanie społeczno-gospodarcze;

3. Stworzenie nieistniejącego dotąd ekosystemu w jego dotychczasowym, historycznym krajobrazie naturalnym i kulturowym [Renaturierung von Ökosystemen in Mitteleuropa, 2009, s. 7].

Zgodnie z założeniami ekologii renaturalizacji, pojęcie renaturalizacji obejmuje zarówno aktywne środki zarządzania biotopami, jak i dopuszczenie otwartych w znacznym stopniu procesów przyrodniczych. Ważnym przykładem może być tutaj renaturalizacja 
lasów, co jest szczególnie istotne w podstawowych „jądrach” parków narodowych czy rezerwatów przyrody.

Przy renaturalizacji coraz bardziej odchodzi się od przyjmowania „stanu naturalnego" na rzecz ochrony procesów przyrodniczych. Można stwierdzić, że ochrona procesón przetamuje (...) zdefiniowanie stanu prayrody. Stanowi on sens tylko w odniesieniu do chronionych krajobrazón kulturowych [Trommer, 2014, s. 17]. Tym samym ochrona procesów przyrodniczych stanowi nową maksymę w ochronie przyrody, w tym zakresie działań na rzecz renaturalizacji.

W ujęciu lokalnym i regionalnym można wskazać następujące strategie renaturalizacyjne:

- renaturalizacja przez ukierunkowany rozwój m.in. z takimi celami, jak zachowanie określonych stadiów: sukcesji, biotopów, gatunków;

- renaturalizacja przez zainicjowany rozwój - przyspieszenie określonych procesów w stosunku do pozostałych;

- renaturalizacja zorientowana na ochroną procesów dzięki zapoczątkowaniu spontanicznego rozwoju - wynikiem mogą być nowe formy „dzikich obszarów", które w przeszłości nie występowały na danym obszarze.

Istotne znaczenie dla wyjaśnienia koncepcji renaturalizacji ma koncepcja świadczeń ekosystemów. Jako świadczenia ekosystemów określa się bezpośrednie i pośrednie wkłady ekosystemów w ludzkie życie, tj. świadczenia i dobra, które przynoszą korzyści człowiekowi bezpośrednio albo pośrednio w ujęciu: gospodarczym, materialnym, zdrowotnym (fizycznym i psychicznym) [Der Wert der Natur..., 2012]. Przy tym wyróżnia się podstawowe typy świadczeń ekosystemów, tj.: świadczenia podstawowe (np. fotosynteza), świadczenia zaopatrzeniowe (np. woda pitna), świadczenia regulacyjne (np. wpływ filtracyjnych górnych warstw gleby na jakość wody gruntowej), świadczenia kulturowe (np. estetyczne znaczenie krajobrazu).

Z perspektywy ekonomicznej przez świadczenia ekosystemów można rozumieć strumienie, które płyna jako rodzaj „dywidendy” od kapitału naturalnego. Kapitał ten stanowi razem z kapitałem rzeczowym, pieniężnym i ludzkim (praca i wiedza) podstawę gospodarowania. W związku z tym, ochrona przyrody i renaturalizacja są nakazem ekonomicznej efektywności i odpowiedzialności za zrównoważony rozwój gospodarczy.

Dla gospodarki dwudziestego pierwszego stulecia zdolność regeneracji przyrody - albo „biopojemność” - staje się czynnikiem limitującym. Obecnie, w szczególności w świetle zmian klimatycznych, trwają intensywne rozważania na temat emisji gazów ze względu na możliwości ich absorpcji przez przyrodę. Stąd też pojawiają się takie koncepcje analizy wpływu człowieka na przyrodę, jak „ślad ekologiczny”. Pojęcie to obejmuje powierzchnię, która pochłania dwutlenek węgla, zaopatrując ludność m.in. w: żywność, bawełnę, drewno, a także obszary, na których występują miasta. Przelicza się ją na powierzchnię ziemi [Wackernagel, 2014, s. 198]. W tym celu wykorzystuje się standardowa jednostkę pomiaru - globalny hektar. Jest to biologiczno-produkcyjny hektar z przeciętną, światową produkcyjnością. W ten sposób w trakcie każdej ludzkiej aktywności można wykazać wielkość produkcyjnej powierzchni, aby była możliwa różnorodność działań ludzkich. 
W odniesieniu do renaturalizacji musi być zakończona „dyktatura krótkiego terminu”, a ekologię trzeba uczynić „kotwica” gospodarczych i politycznych decyzji. Podstawowe kroki zawierają następujące działania: ekonomia unikania wysokiego zużycia zasobów; absolutne rozłączenie wzrostu gospodarczego i zużycia przyrody; zarządzanie środowiskiem w formie europejskiego audytu środowiskowego; ekologiczny wzorzec dla sektora publicznego przy zakupach i innowacjach; polityka, która umożliwia i wspiera większy udział społeczeństwa obywatelskiego w procesach politycznych.

\section{Wymiary renaturalizacji}

Do najważniejszych form funkcjonowania współczesnej renaturalizacji o charakterze lokalnym i regionalnym zalicza się renaturalizację: torfowisk, obszarów odłogowych, obszarów byłych poligonów wojskowych, krajobrazów pokopalnianych, obszarów miejskich. Renaturalizacja ma także podstawowe znacznie na poziomie narodowym i europejskim (w tym przypadku głównie dla działalności Unii Europejskiej). Dotyczy to takich obszarów, jak: polityka ekologiczna, gospodarka rolnicza, gospodarka leśna i powiązanie biotopów, wzrost zużycia energii i wykorzystanie odnawialnych źródeł energii (łącznie z wioskami bioenergetycznymi), działania na rzecz funkcjonowania eko-miast lub ochrony wybrzeży. Natomiast na poziomie globalnym częstokroć wskazuje się na konieczność ochrony klimatu czy problematykę bioróżnorodności. Dla zwierząt i roślin granice polityczne nie maja zasadniczego znaczenia, a właściwie warunki stworzone do funkcjonowania systemów przyrodniczych na granicach politycznych mogą znacząco wspierać procesy przyrodnicze.

Przykładem procesów renaturalizacji może być koncepcja rozwoju obszarów wiejskich i rolnictwa pod względem upowszechniania rolnictwa ekologicznego. Jeszcze niedawno w Polsce wyróżniono cztery typy produkcyjno-ekonomiczne w rolnictwie, ti.: rolnictwo ekstensywne o niskim powiazaniu z rynkiem, rolnictwo mało intensywne o umiarkowanym stopniu powiązania $\mathrm{z}$ rynkiem, rolnictwo intensywne dobrze powiązane $\mathrm{z}$ rynkiem, rolnictwo bardzo intensywne o wysokim powiązaniu z rynkiem. W warunkach współczesnych dla rolnictwa konwencjonalnego charakterystyczne stają się także formy rolnictwa takie, jak: rolnictwo intensywne dobrze powiązane $\mathrm{z}$ rynkiem, oraz rolnictwo bardzo intensywne o wysokim powiazaniu z rynkiem.

Jednakże współczesne rolnictwo uprzemysłowione niezmiernie negatywnie oddziałuje na środowisko przyrodnicze, m.in. przez: zmniejszanie, dzielenie i usuwanie biotopów; nawożenie i pestycydy; wyjaławianie gleb; obniżanie jakości żywności oraz zagrożenia wynikające $z$ masowego chowu zwierząt (np. stosowanie antybiotyków bądź karmienie niezgodne $z$ wymogami fizjologicznymi).

Zupełnie odmienny charakter ma rolnictwo ekologiczne, które stanowi specyficzną oraz najbardziej ekologiczną formę gospodarowania w rolnictwie i produkcji żywności. Żywność jest wytwarzana metodami naturalnymi w czystym i bezpiecznym środowisku, bez zastosowania: nawozów sztucznych i syntetycznych środków ochrony roślin, antybiotyków, hormonów wzrostu i genetycznie modyfikowanych organizmów (GMO). Dzięki wykluczeniu takich substancji, rolnictwo ekologiczne: minimalizuje zanieczysz- 
czenia gleby i wód, ogranicza wypłukiwanie składników pokarmowych z gleby i przyczynia się do zachowania różnorodności biologicznej [Kośmicki, 2009, s. 128-129]. W nawożeniu dopuszcza się zastosowanie: nawozów zielonych, kompostu, obornika i minerałów dostępnych w przyrodzie. Proces produkcji ekologicznej jest kontrolowany przez jednostki certyfikujące, upoważnione w Polsce przez Ministerstwo Rolnictwa i Rozwoju Wsi. Z racji ekonomicznej można więc powiedzieć, że niższe ceny produktów rolnictwa konwencjonalnego po prostu nie odzwierciedlają wszystkich kosztów ekologicznych, które potem sa przerzucane na inne działania związane z koniecznością ochrony procesów przyrodniczych.

\section{Podsumowanie: ekologiczne podstawy gospodarowania z perspektywy koncepcji renaturalizacji}

W teoriach ekologii nadal utrzymują się określone, fałszywe przekonania, które definiuje się jako „mity”. Wymienia się co najmniej cztery takie mity, jak:

1. Mit „naturalnej równowagi” - nie wszystkie jednostki ekologiczne znajdują się w stanie równowagi lub też zbliżają się do takiego stanu;

2. Założenie, że jedynie działalność człowieka niszczy istniejącą równowage przeczą temu naturalne katastrofy biologiczne w dziejach Ziemi, a także udane działania ochronne prowadzące do utrzymania określonych stanów przyrody;

3. Mit, że przyroda jest idealnie działająca ,maszyną", a więc mechanistyczne rozumienie przyrody (,kartezjańsko-newtonowskie”) czy przekonanie o perfekcyjnych i cybernetycznych sprzężeniach zwrotnych w funkcjonowaniu ekosystemów;

4. Mit, że przyroda stanowi globalny i żywy organizm obejmujący cały system Ziemi, w tym biosferę.

Wymienione powyżej mity zostały zakwestionowane przez współczesną wiedzę przyrodnicza, w tym ekologię renaturalizacji. Stąd też współcześnie przyjmuje się, że przemiany w przyrodzie mają duże znaczenie dla rozwoju społeczno-kulturowego i równie duże implikacje dla procesów gospodarowania. Działalność człowieka powinno łączyć się z następującymi założeniami dotyczącymi funkcjonowania systemów ekologicznych:

1. Systemy ekologiczne nie są wcale bezwzględnie stabilne i nie znajdują się w stanie równowagi, ale są dynamiczne;

2. Zakłócenia w strukturze układów ekologicznych powstają również bez udziału człowieka, w wyniku występowania dynamicznych procesów w przyrodzie;

3. Systemy ekologiczne wyróżniają się przede wszystkim określoną dynamiką, lecz zachodzace w nich zdarzenia maja charakter stochastyczny, a tym samym są trudne do przewidzenia albo nawet nie są możliwe do prognozowania;

4. Ekosystemy nie są organizmami, a charakter ich struktur wewnętrznych i możliwości samoregulacji nadal pozostaja przedmiotem badań;

5. Procesy zmian $\mathrm{w}$ przyrodzie są naturalne, a nawet pozytywne i nieodzowne do utrzymania przyrody jako całości; 
6. Biologia ewolucyjna i ekologia renaturalizacji umożliwiaja wyjaśnianie przyczyn zmienności przyrody, a ramowe warunki przyrodnicze stanowia globalną perspektywę działań na rzecz utrzymania procesów przyrodniczych.

Ostatecznym celem ochrony przyrody staje się utrzymanie naturalnych procesów, tj.: procesów przystosowania biologicznego, dalszego rozwoju procesów ewolucyjnych, ale także nowych struktur biologicznych włącznie z tworzeniem nowych gatunków. Ochrona przyrody prowadzi do zabezpieczenia istnienia ogólnego zakresu gatunków roślin i zwierząt oraz ich wspólnot życiowych w określonych uwarunkowaniach przyrodniczych i historycznych. Utrzymanie procesów ewolucji oznacza zachowanie takich warunków, gdzie mogą pojawiać się nowe gatunki biologiczne, a dobór naturalny nadal może spełniać swoje podstawowe funkcje.

W ujęciu globalnym proces renaturalizacji wymaga uwzględnienia następujących założeń dotyczących działań człowieka w biosferze:

- Ziemia to otwarty termodynamicznie, lecz nierosnący fizycznie system, w którym gospodarka jest jedynie subsystem biosfery - sa granice biofizycznego strumienia zasobów naturalnych, które płyną od ekosystemu globalnego (biosfery) do subsystemu gospodarki, a te później w formie odpadów i zanieczyszczeń ponownie do niego powracaja;

- $\quad$ istnieje konieczność uwzględniania wzorców zrównoważonego systemu z wysoką jakością życia wobec wszystkich mieszkańców Ziemi (nie tylko ludzi, a także pozostałych gatunków) w obrębie granic globalnego ekosystemu;

- analiza kompleksowych systemów, takich jak Ziemi, łączy się z dużą niepewnością i nieodwracalnymi zmianami;

- $\quad$ elastyczne i możliwe do praktycznego przeprowadzenia strategie działań wymagaja głębszego zrozumienia systemu globalnego i systemów lokalnych (ekosystemów), jak również funkcjonowania gospodarki i społeczeństwa [Binswanger, 2010];

- możliwości funkcjonowania biosfery w znacznej mierze są zabezpieczone dzięki tym ekosystemom, których jeszcze dotąd nie wykorzystał człowiek.

Społeczeństwo (i gospodarka) nie może bez końca powiększać się (przynajmniej w sensie fizycznym). Ze swej natury gospodarowanie jest procesem, który z racji jego powiązania z systemami przyrodniczymi nie ma szans osiagania jakiegoś celu - ostatecznego stanu, który będzie stanem statycznym. W konsekwencji niezbędne jest nieustanne kształtowanie i dostosowywanie się gospodarki do nowych uwarunkowań społeczno-ekologicznych. Z perspektywy renaturalizacji można jedynie oceniać, jakie strategie gospodarowania były korzystne w przeszłości. Każda nowo powstająca strategia jest tylko jednym z elementów współuczestniczenia w kształtowaniu warunków przyszłych wraz z przemianami w innych systemach - w tym przyrodniczych. Co więcej, sama ocena renaturalizacji pozostaje pod wpływem przyjętych systemów wartości, które decyduja o: tworzeniu, doborze i interpretacji jej rezultatów.

Renaturalizacja wyznacza proces prowadzący do ukształtowania się zrównoważonego stanu gospodarki i społeczeństwa, które uwzględniają podstawowe wymogi ekonomiczne i społeczno-kulturowe przy zachowaniu przyrodniczych podstaw gospodarki i spo- 
łeczeństwa. Renaturalizacja stanowi nowy sposób podejścia związany z ochroną przyrody i polityką ekologiczną, a także zrównoważonym procesem gospodarowania.

\section{Wkład autorów w powstanie artykułu}

dr hab. prof. nadzw. Eugeniusz Kośmicki - opracowanie koncepcji, przegląd literatury, analiza danych, pisanie $-50 \%$

dr hab. Dariusz Pieńkowski - redakcja naukowa, przegląd literatury, analiza danych i pisanie $-50 \%$

\section{Literatura}

Binswanger H., 2010, Vorwärts zur Mässigung. Perspektiven einer nachbaltigen Wirtschaft, Murmann, Hamburg.

Crutzen P. J., 2001, Das Raumscbiff Erde hat keinen Notausgang, Fischer, Frankfurt am Main.

Döhler F., Grünig M., Langsdorf S., 2014, Ökostadt - Vision und Wirklichkeit, [w:] ReNaturierung Gesellschaft im Einklang mit der Natur, von H. Leitschuh, G. Michelsen, U.E. Simonis, J. Sommer, E.U. von Weizsäcker (Hrsg.), Hirzel, Stuttgart.

Encyklopedia Powszechna PWN, 1976, t. 4, Państwowe Wydawnictwo Naukowe, Warszawa.

Fink P., Riecken U., 2014, Biotopverbund und über Grenzen binweg!, [w:] Re-Naturierung. Gesellschaft im Einklang mit der Natur, H. von Leitschuh, G. Michelsen, U. E. Simonis, J. Sommer, E. U. von Weizsäcker (Hrsg.), Hirzel, Stuttgart.

Goetel W., 1971, Racjonalna gospodarka zasobami prsyrody, Państwowe Wydawnictwo Naukowe, Warszawa.

Härdtke W. G. von Oheimb, 2014, Pflege von Heidelandschaften, [w:] Re-Naturierung. Gesellschaft im Einklang, mit der Natur, von H. Leitschuh, G. Michelsen, U.E. Simonis, J. Sommer, E.U. von Weizsäcker (Hrsg.), Hirzel, Stuttgart.

Kant R., 2014, Raubbau an Wäldern, [w:] Re-Naturierung. Gesellschaft im Einklang mit der Natur, von H.Leitschuh, G. Michelsen, U. E. Simonis, J. Sommer, E. U. von Weizsäcker (Hrsg.), Hirzel, Stuttgart.

Kośmicki E., 2009, Podstawowe problemy ekologizacji rolnictwa. Próba eksplikacji gtównych zagadnień, [w:] Rožój zrównoważony ze szczególnym uñalędnieniem obszarów wiejskich, B. Fiedor, R. Jończy (red.), Wydawnictwo Uniwersytetu Ekonomicznego we Wrocławiu, Wrocław.

Müller M., K. Niebert, 2014, Die Ökologie als Anker politischer Entscheidungen, [w:] ReNaturierung. Gesellschaft im Einklang mit der Natur, von H. Leitschuh, G. Mischelsen, U.E. Simonis, J. Sommer, E.U. von Weizsäcker (Hrsg.), Hirzel, Stuttgart.

Naturkapital Deutschland - TEEB DE, 2012, Der Wert der Natur für Wirtschaft und Gesellschaft, Bundesamt für Naturschutz, Bonn. 
Piechocki R., Finck P., Natho S., Riecken U., Jesell B., 2014, Renaturieng-zum Naturschutz der Zukunft, [w:] Re-Naturierung. Gesellschaft im Einklang mit der Natur, von H. Leitschuh, G. Mischelsen, U.E. Simonis, J. Sommer, E. U. von Weizsäcker (Hrsg.), Hirzel, Stuttgart.

Pohl M., Neuberger A., Kristof K., 2014, Renaturierung - eine Aufgabe der Umweltpolitik, [w:] Re-Naturierung. Gesellschaft im Einklang mit der Natur, von H. Leitschuh, G. Michelsen, U.E. Simonis, J. Sommer, E. U. von Weizsäcker (Hrsg.), Hirzel, Stuttgart.

Renaturierung von Ökosystemen in Mitteleuropa, 2009, S. Zerbe, G. Wiegleb (Hrsg.), Universitätsverlag, Berlin.

Schmuck P., 2015, Die Kraft der Vision. Plädoyer für eine neue Denk - und Lebenskultur, Oekom, München.

Succow M., Jeschke L., 2014, Mehr Wildnis wagen, [w:] Re-Naturierung. Gesellschaft im Einklang mit der Natur, von H. Leitschuh, G. Michelsen, U.E. Simonis, J. Sommer, E.U. von Weizsäcker (Hrsg.), Hirzel, Stuttgart.

TEEB, 2010, Die ökonomische Bedeutung der Natur in Entscheidungsprozesse integrieren. Ansatz, Schlussfolgerungungen und Empfehlungen von TEEB. Eine Synthese, Bundesamt für Naturschutz, Bonn.

Trommer G., 2012, Schön wild. Warum wir unsere Kinder Wildnis brauchen, Oekom, München.

Trommer G., 2014, Wilde Dinge-Gewissheit obne Stubl und Lebne, [w:] Re-Naturierung. Gesellschaft im Einklang mit der Natur, von H. Leitschuh, G. Michelsen, U.E. Simonis, J. Sommer, E.U. von Weizsäcker (Hrsg.), Hirzel, Stuttgart.

Wackernagel M., Beyers B., 2010, Der Ecological Footprint. Die Welt neu vermessen, Europäische Verlagsanstalt, Hamburg.

Wackernagel M., 2014, Der Grundkonflikt - der „,̈kologische Fussabdruck“", [w:] Renaturierung. Gesellschaft im Einklang mit der Natur, von H. Leitschuh, G. Michelsen, U.E. Simonis, J. Sommer, E.U. von Weizsäcker (Hrsg.), Hirzel, Stuttgart. 